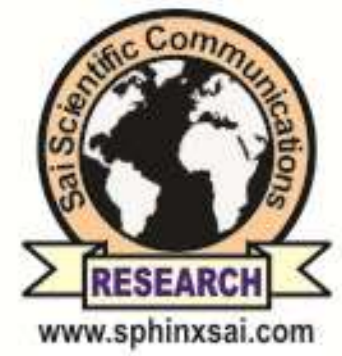

\title{
Antiseptic Formulation of Libo Extract (Ficus Varieagata Blume)
}

International Journal of ChemTech Research CODEN (USA): IJCRGG, ISSN: 0974-4290, ISSN(Online):2455-9555

Vol.11 No.05, pp 281-284,

2018

\author{
Rolan Rusli ${ }^{1,2, \star}$, Mirhansyah Ardana ${ }^{1,3}$, Shyntia Mutiarasari Tambunan ${ }^{1}$ \\ 'Laboratorium Penelitian dan Pengembangan Kefamasian "Farmaka Tropis", \\ Fakultas Farmasi, Universitas Mulawarman, Samarinda, Kalimantan Timur, Indonesia \\ JI. Penajam Kampus Unmul Gn. Kelua, Samarinda \\ ${ }^{2}$ KelompokBidangllmu “Kimia Farmasi”, FakultasFarmasi, Universitas Mulawarman, \\ Samarinda, Kalimantan Timur, Indonesia JI. Penajam Kampus Unmul Gn. Kelua, \\ Samarinda \\ ${ }^{3}$ KelompokBidangllmu “FarmasetikadanTeknologiFarmasi”, FakultasFarmasi, \\ UniversitasMulawarman, Samarinda, Kalimantan Timur, Indonesia Jl. Penajam \\ Kampus Unmul Gn. Kelua, Samarinda
}

\begin{abstract}
Libo (Ficus varieagata Blume) is a wild plant in East Kalimantan. Secondary metabolites of Libo were alkaloids, flavonoids, steroids, terpenoids, and tannins. Libo extracts have potential as an antibacterial. The aim of this research was to a formulation of libo extracts as antiseptic. The formula of antiseptic was Libo fruit extract, tween 20, Sodium Lauryl Sulphate, $\mathrm{NaCl}$, Propylene glycol, and aquadest. The antiseptic was tested by $\mathrm{pH}$, viscosity, density, and performed with the national standard of Indonesia. The best antibacterial activity of antiseptic from libo fruit extracts was F3 formula.

Keywords : Libo (Ficus varieagata Blume), extract, antiseptic, formulation.
\end{abstract}

\section{Introduction}

Libo plants (F.variegata, Blume) are native plants from East Kalimantan. ${ }^{1}$ Libo plant has secondary metabolites, alkaloids, saponin,phenol, flavonoids,tannin, and steroids/terpenoids. ${ }^{1-6}$ The libo plant shown activity as a larvicidal, cytotoxic, antioxidant,and antibacterial. ${ }^{1}$ Another researcher has reported antibacterial activity of Libo against bacteriaEscherichia coli and Staphylococcus aureus. ${ }^{3-5}$

To maximize the use of libo, it needs to make in an antibacterial formulation. An antibacterial formulation is omitted much required for daily purposes one of them is liquid soap. Soap can be used to prevent infectious diseases, caused by bacteria. In other words, soap can be used as a preventive drug by cleaning the body so that the possibility of disease will be reduced. Liquid soap is widely produced because its use is more practical.

International Journal of ChemTech Research, 2018,11(05): 281-284.

DOI= http://dx.doi.org/10.20902/IJCTR.2018.110530 


\section{Experimental}

\section{Materials}

Libofruit (Ficus variegata Blume), Ethanol, Nutrient Agar, Escherichia coli, Staphylococcus aureus, Tween 20, Sodium Lauryl Sulphate, $\mathrm{NaCl}$, Propylene glycol, and aquadest.

\section{Procedure}

\section{Extraction}

Libo fruit was sorted, washed, thinly sliced, and dried at $80{ }^{\circ} \mathrm{C}$. Dry of Libo fruit was powdered and extracted by maceration method using ethanol solvent. A Solution of extracts was concentrated using a rotary evaporator and evaporated over the water bath to obtain a dry extract.

\section{Formulation}

Extracts dissolved with tween 20, and in another container, Sodium Lauryl Sulphate was dissolved with aquadest, then mixed. $\mathrm{NaCl}$ and Propylene glycol was added into solution while stirred until yielding a homogenous antiseptic.

\section{Evaluation of $\mathbf{p H}$}

Antiseptic of Libo fruit (10 mL) was measured using $\mathrm{pH}$ meter.

\section{Evaluation of Viscosity}

Antiseptic of Libo fruit $(15 \mathrm{~mL})$ inserted in a cylindrical container. Testing of viscosity was performed using a cylindrical type rheoys viscometer at $10 \mathrm{rpm} 25^{\circ} \mathrm{C}$.

\section{Evaluation of Density}

A clean and dry pycnometer weighed. Filled pycnometer with antiseptic and weighed again. Density was calculated by equation 1 .

$$
\text { Density }=\frac{\text { Filled weigh of pycnometer }(g)-\text { empty weigh of pycnometer }(g)}{\text { volume }(m L)}
$$

\section{Evaluation of Antibacterial Activity}

Sterile nutrient agar medium $(10 \mathrm{~mL})$ was inoculated with $0.02 \mathrm{~mL}$ of suspension of bacteria (Escherichia coli and Staphylococcus aureus) and homogenized and then poured into a petri dish, then left medium to solidify. Paper disc after dipped into an antiseptic of libofruit is placed over the medium, and incubated at $37{ }^{\circ} \mathrm{C}$ for 24 hours. Clear zone was measured using a micro screw meter.

\section{Results and Discussion}

\section{Formulation and Their Evaluation}

Antiseptic made in this research is a liquid soap with extract of libo fruit as an active ingredient. Liquid soap is a more practical and entertaining form than other types of soap. Liquid soap as made, it is formulated with libo fruit extract, tween 20, NaCl, Propylene glycol, Sodium Lauryl Sulphate, and adding aquadest until 25 $\mathrm{mL}$. All of their soap compositions shown in Table 1. 
Table 1Compound composition of antiseptic from libo

\begin{tabular}{|l|l|l|l|}
\hline Composition & F1 & F2 & F3 \\
\hline Libo extracts & $2.5 \mathrm{~g}$ & $2.5 \mathrm{~g}$ & $2.5 \mathrm{~g}$ \\
\hline Sodium Lauryl Sulphate & $1.25 \mathrm{~g}$ & $1.875 \mathrm{~g}$ & $2.5 \mathrm{~g}$ \\
\hline Tween 20 & $2.5 \mathrm{~g}$ & $2.5 \mathrm{~g}$ & $2.5 \mathrm{~g}$ \\
\hline $\mathrm{NaCl}$ & $2.5 \mathrm{~g}$ & $2.5 \mathrm{~g}$ & $2.5 \mathrm{~g}$ \\
\hline Propylene glycol & $1.25 \mathrm{~g}$ & $1.25 \mathrm{~g}$ & $1.25 \mathrm{~g}$ \\
\hline Aquadest & $\mathrm{ad} 25 \mathrm{~mL}$ & $\mathrm{ad} 25 \mathrm{~mL}$ & $\mathrm{ad} 25 \mathrm{~mL}$ \\
\hline
\end{tabular}

Libo fruit extract used as an antiseptic active ingredient (antibacterial). Tween 20 is used as a solvent extract because it is more hydrophilic than other types of tweens. The use of tween 20 can produce a higher viscosity compared to the use of tween 80 . The concentration uses $10 \%$, which according to Rowe ${ }^{7}$ ranges of tween 20 serves as a solubilizing agent ranges from $1-15 \%$.

The concentration of Sodium Lauryl Sulphate was used $10 \%$ for maximum detergency at a concentration. ${ }^{7}$ Sodium Lauryl Sulphate is a molecule surfactant and has a hydrophilic group and a lipophilic group that can unite a mixture of water and oil. Sodium Lauryl Sulphate plays a role to reduce surface tension of the solution so that it can dissolve the oil as well as form micro emulsion and the foam is formed.

The addition of $10 \% \mathrm{NaCl}$ will make soap more viscous. ${ }^{8}$ Propylene glycol $5 \%$ serves as a humectant (moisturizer) to withstand evaporation of water in antiseptic and in the skin. It can provide a sense of comfort in the skin with the use of this liquid soap. Table 2 .

The result of evaluation of antiseptic from libo fruit extracts i.e. $\mathrm{pH}$, viscosity, and density shown in

Table 2results of test of pH, viscosity, and density of antiseptic from Libo

\begin{tabular}{|l|l|l|l|}
\hline Formulation & pH & Viscosity $(\mathbf{c p})$ & Density $(\mathbf{g} / \mathbf{m L})$ \\
\hline F1 & 4.81 & 3.3328 & 1.3460 \\
\hline F2 & 4.63 & 7.4305 & 1.3445 \\
\hline F3 & 4.64 & 13.8213 & 1.3616 \\
\hline
\end{tabular}

The antiseptic from libo fruit has a $\mathrm{pH}$ in the 4-5 range. The results of statistical tests showed that the $\mathrm{pH}$ values of the antiseptic formulations were not significantly different. However, the $\mathrm{pH}$ of antiseptic has not met in the range of (6-8) pH the SNI standard. ${ }^{9}$

The resulting antiseptic viscosity was 3-14 cP. The result of statistic test showed that the viscosity of the antiseptic formulations was not significantly different. However, all antiseptic viscosities also did not meet with the range of viscosity standards $(42.5$ to $12,000 \mathrm{cP}){ }^{9}$

The density of antiseptic from libo fruit extracts obtained about $1.3 \mathrm{~g} / \mathrm{mL}$. The density of the antiseptic is slightly greater than the density of the liquid soap based on the SNI standard $(1.01-1.10 \mathrm{~g} / \mathrm{mL}){ }^{9}$

Table 3results of antibacterial activity of antiseptic from Libo

\begin{tabular}{|l|l|l|}
\hline \multirow{2}{*}{ Formulation } & \multicolumn{2}{|l|}{ Diameter of bactericide zone $(\mathbf{m m})$} \\
\cline { 2 - 3 } & Staphylococcus aureus & Escherichia coli \\
\hline F1 & 1.608 & 0.430 \\
\hline F2 & 2.539 & 1.112 \\
\hline F3 & 3.638 & 1.220 \\
\hline
\end{tabular}




\section{Antibacterial Activity of Antiseptic}

The results of the antibacterial activity test of antiseptic liquid soap shown in Table 3. Table 3 indicates that all of the antiseptics has enough killing power against the test bacteria (Escherichia coli and Staphylococcus aureus). With increasing concentration of SLS in antiseptic also increases the antibacterial activity (increase in diameter of a clear zone) and highest clear area found in antiseptic F3. Based on the statistical test, that the best antiseptic is F3 antiseptic. However, other evaluation parameters are not in agreement with SNI so that additional materials are needed to improve the preparation to suit the SNI.

\section{Conclusion}

Libo fruit extracts (Ficus variegata) can be applied as a liquid antiseptic. The antiseptic formula was Libo fruit extracts, tween 20, Sodium Lauryl Sulphate, $\mathrm{NaCl}$, Propylene glycol, and aquadest. The best antiseptic formulation was F3 formula.

\section{Acknowledgements}

Thanks to Laboratorium Penelitiandan Pengembangan Kefamasian "Farmaka Tropis", Fakultas Farmasi, Universitas Mulawarman for the facilities and research permit given.

\section{References}

1. Rijai, L. Potensitumbuhanlibo (Ficus variegata, Blume) sebagaisumberbahanfarmasipotensial. J. Trop. Pharm. Chem., 2013. 2, 3: 166-179. DOI: https://doi.org/10.25026/jtpc.v2i3.63

2. Febrina, L., Rusli, R., and Muflihah, F., Optimalisasi Ekstraksi Dan Uji Metabolit Sekunder Tumbuhan Libo (Ficus variegate Blume). J. Trop. Pharm. Chem., 2015, 3, 2:7481.DOI: https://doi.org/10.25026/jtpc.v3i2.153

3. Rusli, R., Hardina, M.P., Muflkihah, F., and Rahmadani, A., Trop. Pharm. Chem., 2015, 3, 2: 124130.DOI: https://doi.org/10.25026/jtpc.v3i2.98

4. Ningsih, B.A., Rahmadani, A., Fadraersada, J., Rusli, R., 2016. Prosiding Seminar Nasional Tumbuhan Obat Indonesia Ke-50. Samarinda.

5. $\quad$ Ningsih, B., Rahmadani, A., Fadraersada, J., Rusli, R., Aktivitasanti bakteridanantioksidan isolatfraksietilasetatbuahlibo (Ficus variegate Blume.). Mulawarman Pharm. Conf. Proc., 2016. 2,3: 114-120. http://prosiding.farmasi.unmul.ac.id/index.php/mpc/article/view/95

6. $\quad$ Saleh, R.A., Rahmadani, A., Lizma, F., Rusli, R., Aktivitas Antibakteri Kulit Batang Libo (Ficus variegate Blume). Mulawarman Pharm. Conf. Proc., 2016. 2. 3: 357-

363.http://prosiding.farmasi.unmul.ac.id/index.php/mpc/article/view/133

7. Utami, D.N., Rahmadani, A., Fadraersada, J., Rusli, R., Mulawarman Pharm. Conf. Proc., Aktivitas antioksidankulitbatanglibo (Ficus variegata Blume). 2016. 2.3: 138-141. http://prosiding.farmasi.unmul.ac.id/index.php/mpc/article/view/98

8. Rowe, R.C., Sheskey, P.J., Cook, W.G., Fenton, M.E., Handbook of Pharmaceutical Excipients, Pharmaceutical Press, London.2012.

9. Varcin M., Vandael A., and Zier-Vercammen J., Pharmacy Compounding of Medicinal Shampoo: An Update, J. Pharm Belg, 2012. 4: 38-48.https://www.ncbi.nlm.nih.gov/pubmed/23350210

10. SNI 06-4085-1996 atau Departemen Kesehatan Republik Indonesia, Mutudan Cara Uji Sabun Mandi, Direktorat Jenderal Pengawasan Obatdan Makanan, Jakarta, 1996 